\title{
Penilaian Kinerja Rumah Sakit Dengan Menggunakan Pendekatan Balanced Scorecard: Systematic Review
}

\section{Assessment of Hospital Performance Using Balanced Scorecard Approach: Systematic Review}

\author{
Samuel Lay Riwu', Adik Wibowo ${ }^{2}$, Kevin Chrisanta Budiyatno ${ }^{3}$ \\ ${ }^{1,3}$ Program Studi Administrasi Rumah Sakit, FKM Universitas Indonesia \\ ${ }^{2}$ Departemen Administrasi dan Kebijakan Kesehatan, Universitas Indonesia \\ email: samuel.lay@ui.ac.id or samuelriwu@yahoo.com
}

\begin{abstract}
ABSTRAK
Pengukuran kinerja selama ini selalu hanya melihat dari segi finansial oleh semua perusahaan, termasuk rumah sakit. Pendekatan konsep Balanced Scorecard (BSC) merupakan salah satu alternatif dalam mengukur kinerja. Selain mempertimbangkan faktor keuangan juga mempertimbangkan faktor non keuangan sehingga memberikan penilaian yang komprehensif kepada manajemen. Tujuan dari penelitian ini adalah untuk melihat bagaimana BSC digunakan pada rumah sakit di seluruh dunia dan melihat apakah itu bisa diterapkan pada rumah sakit di Indonesia. Metode dalam penelitian ini menggunakan metode systematic review. Kami awalnya melakukan pencarian manual pada tanggal 17 Maret 2021 dengan mempelajari artikel investigatif terkait Hospital BSC yang dimuat di ProQuest, EBSCO, SpringerLink, Sciencedirect dan Scopus. Kemudian, di luar akses UI, pencarian artikel juga dilakukan melalui Google Scholar dan selain mendapatkan artikel berbahasa Indonesia melalui Garuda ristekbrin. Hasil Penelitian ini menemukan bahwa manfaat penerapan BSC di rumah sakit antara lain berguna untuk mengevaluasi rencana strategis penilaian kinerja dalam manajemen rumah sakit, menyeimbangkan kinerja keuangan dan non keuangan, membantu menyelaraskan visi, misi dan tujuan organisasi, serta mendorong perubahan lingkungan kerja sesuai terhadap kebutuhan rumah sakit. Studi ini juga menemukan bahwa tantangan dalam menerapkan BSC adalah proses adopsi dan implementasi yang diperlukan rumah sakit di Indonesia, BSC harus diadopsi dan diterapkan secara bertahap dalam skala yang lebih luas. Hal ini mengindikasikan bahwa diharapkan instansi kesehatan, termasuk rumah sakit, dapat menerapkan konsep BSC.
\end{abstract}

Kata Kunci: Balanced Scorecard, Kinerja, Rumah Sakit

\section{ABSTRACT}

Performance measurements have always only been looked at financially by all companies, including hospitals. The Balanced Scorecard (BSC) concept approach is one of the alternatives in measuring performance. In addition to considering financial factors also consider non-financial factors so as to provide a comprehensive assessment to management; The aims of this study was to review the application of BSC in hospitals in various countries and assess the feasibility of its application to hospitals in Indonesia. The methods in this study use systematic review methods. We initially conducted a manual search on March 17, 2021, by studying investigative articles related to Hospital BSC published in ProQuest, EBSCO, SpringerLink, Science Direct, and Scopus. Then, outside of UI access, article search is also done through Google Scholar and in addition to getting Indonesian articles through Garuda ristekbrin. The results of this study found that the benefits of implementing BSC in hospitals include useful for evaluating strategic performance assessment plans in hospital management, balancing financial and nonfinancial performance, helping to align the vision, mission, and objectives of the organization, and driving changes in the work environment according to the needs of hospitals. The study also found that the challenge in implementing BSC is the process of adoption and implementation required of hospitals in Indonesia, BSC must be adopted and applied gradually on a wider scale. This indicates that it is expected that health agencies, including hospitals, can implement the BSC concept.

Keywords: Balanced Scorecard, Performance, Hospital 


\section{PENDAHULUAN}

Balanced scorecard (BSC) merupakan alat pengukuran kinerja manajemen yang memberikan pandangan ringkas dan komprehensif tentang suatu organisasi dengan berfokus pada cakrawala yang lebih luas yang tidak hanya dari perspektif keuangan saja. Dalam pelaksanaan sistem BSC, organisasi didorong untuk mengukur faktor-faktor yang mempengaruhi keluaran keuangan dengan memilih ukuran dari tiga kategori atau perspektif tambahan: pelanggan, prosedur internal, dan pembelajaran dan pertumbuhan.

Pengukuran kinerja rumah sakit saat ini sering menonjolkan sisi keuangan, manajemen sering dikatakan berhasil apabila telah mencapai tingkat keuntungan yang tinggi dari segi pendapatan yang kemudian akan diikuti dengan imbalan jasa pelayanan bagi karyawan yang juga meningkat.(Astuti et al., 2020) Penilaian kinerja suatu perusahaan tidak semata-mata didasarkan pada kinerja keuangan saja, yang dapat menyesatkan karena kinerja keuangan yang baik saat ini bisa dicapai dengan mengorbankan kepentingan jangka panjang suatu perusahaan dan begitu juga sebaliknya, kinerja keuangan yang kurang baik dalam jangka pendek bisa saja terjadi karena perusahaan melakukan investasi-investasi demi kepentingan jangka panjang.(Amos et al., 2021) Untuk mengatasi masalah ini, maka diciptakan suatu metode pendekatan yang mengukur kinerja perusahaan perangkat BSC mempertimbangkan 4 aspek yaitu aspek keuangan, pelanggan, proses bisnis internal, serta proses pertumbuhan dan pembelajaran.

Adanya kelebihan yang dimiliki oleh BSC ini mendorong semakin banyaknya perusahaan yang ingin mengimplementasikan konsep Balanced Scorecard. Hasil penelitian yang dilakukan oleh Beatriz, Sanchez, Maria, Pires, dan Broccardo di St. Vincent pada 2010-2012 menunjukkan Peningkatan kepuasan pasien (88\% menjadi $96 \%$ ), peningkatan persentase pasien (43\% menjadi 68\%), peningkatan persentase pasien yang dianggap berisiko (40\% hingga 90\%), penurunan insiden MRSA (methicillinresistant to staphylococcus aureus), penurunan insiden penurunan dan insiden pengobatan, penurunan tingkat rawat inap, tingkat kekosongan dan tingkat turnover.(Broccardo, 2015) Selain itu, manfaat BSC di sektor kesehatan adalah peningkatan kualitas perawatan dan hasil perawatan untuk pasien karena berfokus pada pasien, peningkatan manajemen dan akuntabilitas medis dengan tujuan yang jelas, peningkatan komunikasi, dan merangsang diskusi baru antara dokter dan manajemen tentang visi dan strategi.(Korneles et al., 2019) 
Samuel Lay Riwu, Adik Wibowo, Kevin Chrisanta Budiyatno : Penilaian Kinerja Rumah Sakit Dengan ....

Keberhasilan kinerja perusahaan di Indonesia dinilai kurang baik apabila ditinjau dari keseluruhan perspektif BSC, dengan total skor kinerja 53,40\% tergolong tidak sehat. Dinilai baik jika dilihat dari perspektif pelanggan dan dari perspektif pertumbuhan dan pembelajaran, tetapi kurang baik dari perspektif keuangan dan bisnis internal, dengan kinerja keuangan 1,00\% dari bobot yang ditentukan $20 \%$ dan kinerja bisnis internal $17,10 \%$ dari bobot yang ditentukan sebesar $30 \%$. Hal ini dapat disebabkan karena kinerja keuangan dan operasional perusahaan belum optimal. Secara keseluruhan, kinerja perusahaan dinilai "Tidak Sehat" dalam kategori BBB dari tahun 2012 hingga 2015, dengan Total Skor Kinerja 53,40\%.(Yulianti \& Diyani, 2017)

Munculnya BSC sebagai salah satu sistem pengukuran kinerja modern baru dapat dilihat sebagai solusi alternatif bagi penggunaan sistem pengukuran kinerja bisnis tradisional yang hanya fokus pada kinerja keuangan dan memberikan sedikit perhatian pada tindakan non-keuangan, dan menempatkan perhatian manajemen pada kinerja jangka pendek.(Martunis et al., 2020) Ini dapat menyesatkan perusahaan bisnis terus meningkatkan dan tujuan inovasi yang merupakan dua hal penting aspek dalam lingkungan bisnis yang terus berubah saat ini. Tujuan dari penelitian ini adalah untuk melihat bagaimana BSC digunakan di rumah sakit di seluruh dunia dan untuk melihat apakah BSC dapat diterapkan pada rumah sakit di Indonesia.

\section{METODE}

Metode yang digunakan dalam penelitian ini adalah tinjauan sistematis, teknik pencarian yang berbeda digunakan untuk menemukan studi yang relevan. Tinjauan sistematis dipilih berdasarkan kriteria inklusi penelitian dan didasarkan pada diagram alur PRISMA 2020. (Page et al., 2021) Dalam database elektronik, pencarian sistematis dilakukan untuk menemukan artikel yang memenuhi syarat. Pencarian artikel menggunakan instrumen Preferred Reporting Items for Systematic Review and MetaAnalyses (PRISMA) dan diagram alur yang disusun berdasarkan dengan panduan checklist PRISMA 2020, untuk studi yang dipilih dalam proses pencarian dan penilaian kelayakan artikel secara berurutan.

Pencarian artikel dan informasi dilakukan secara komprehensif melalui database elektronik dari berbagai situs sebagai sumber data. Kami mulai melakukan pencarian manual pada tanggal 17 Maret 2021 diawali dengan membuka https://remote-lib.ui.ac.id, yang kemudian mencari dari laman lain yaitu ProQuest, EBSCO, Springer Link, Science Direct, Scopus, dan Taylor \& Francis Online. Kemudian, di luar akses UI, pencarian 
artikel juga dilakukan melalui Google Scholar dan sebagai tambahan untuk mendapatkan artikel berbahasa Indonesia, dilakukan melalui Garuda.ristek brin. kami mengidentifikasi semua publikasi akademis sebelumnya menggunakan kata kunci "Balanced Scorecard", "hospital", "health care, "health care organizations," "hospital performance measurement" dan "hospital performance management," dari database penelitian berbasis Internet utama, kemudian kami menerapkan string pencarian ke judul, abstrak, dan kata kunci publikasi akademis dalam database.

Pencarian artikel menekankan pada penggunaan BSC dalam organisasi pelayanan kesehatan terutama dalam pengaturan rumah sakit adalah kriteria pertama kami untuk inklusi dan eksklusi. Kriteria inklusi artikel yang kami anggap memenuhi syarat untuk ditinjau secara sistematis adalah sebagai berikut: 1) kriteria pembatasan terkait dengan jenis bahasa (bahasa Inggris), dokumen yang dianggap sesuai adalah sebagai berikut: jurnal, artikel, studi asli, tesis, dan disertasi, serta ketersediaan dokumen lengkap dan gratis, diterbitkan dari (2011-2021), area manajemen rumah sakit; 2) artikel/ jurnal yang berupa hasil penelitian terpublikasi, yang full-text dan free-accessed dari kata kunci yang dipakai; 3) hanya artikel dari jurnal peringkat Q1 hingga Q4 yang diusulkan oleh Scimago Journal \& Country Rank (SJR); Pencarian dilakukan dengan menggunakan rumus PICO dengan kata kunci : P (Population) ; Rumah sakit ; I (Intervensi); Pengukuran kinerja dengan menggunakan pendekatan Balanced Scorecard, C (Comparison); Pengukuran kinerja secara tradisional O (Outcome); Peningkatan kinerja yang optimal, yang tidak hanya dari segi keuangan saja tetapi juga dari perspektif non keuangan. Selanjutnya, kriteria eksklusi dalam penulisan ini yaitu artikel/ jurnal yang outcome nya tidak berhubungan dengan pelayanan di rumah sakit dan desain studi yang tidak relevan.

Berikut rincian strategi pencarian yang dilakukan melalui 7 database online sebagai berikut: Pencarian di database EBSCO: Boolean/Phrase: Balanced Scorecard AND Performance AND Hospital OR Health Care Expanders: Apply equivalent subjects, Limiters: Full Text Publication Date 2011-2021 Tipe, Language; English, Database: CINAHL Plus with Full Text MEDLINE with Full Text AND Dentistry \& Oral Sciences Source. Pencarian di database Scopus: (TITLE-ABS-KEY (balanced AND scorecard OR BSC AND hospital OR health AND care OR key AND performance)) AND (balanced AND scorecard AND hospital OR health AND care AND performance) AND (LIMITTO (OA, "all")) And (Limit-To (Pubyear, 2011-2021)) And (Limit-To (Subjarea,"Medi") Or Limit-To (Subjarea, "Busi")) 
Samuel Lay Riwu, Adik Wibowo, Kevin Chrisanta Budiyatno : Penilaian Kinerja Rumah Sakit Dengan ....

Pencarian di database Proquest: ((Balanced Scorecard and Performance and Hospital or Health Care (*Applied Filters*Results Have Been Filtered. *Last 5 Years *Public Health*English*International Journal of Environmental Research and Public Health")) Pencarian di database PUBMED Balanced Scorecard and Performance and Hospital* Free full text*. Pada pencarian di database Taylor\&Fancis Online: [All: Balanced Scorecard and performance and hospital or health care] AND [All Subjects: Health and Social Care] AND [Publication Date: (2011 TO 2021)]. Pencarian di database ScienceDirect: Balanced Scorecard and Performance and Hospital or Health Care *Refine by: Subscribed journals* Years: 2011-2021, *International Journal of Hospitality Management *Open access.

Pencarian seluruh judul dan abstrak melalui database elektronik dinilai secara menyeluruh untuk menilai hasil yang diinginkan dan disaring untuk kelayakannya. Kami memeriksa kelengkapannya, pencarian awal didapatkan 28.726 artikel yang sesuai dengan kata kunci. Kemudian dimasukkan faktor inklusi seperti pembatasan tahun publikasi dan hanya artikel yang berbahasa Inggris dan bahasa Indonesia, kemudian pemeriksaan duplikat dilakukan menggunakan mendeley, kemudian 1828 dokumen diperoleh yang bebas dari duplikat, dan kemudian 1635 artikel dikeluarkan karena artikel tidak relevan dengan kata kunci (PICO), teks lengkap tidak tersedia, dan artikel berbayar. Akhirnya, penelitian ini hanya memperoleh 11 artikel untuk sintetis kualitatif dan akan dibaca secara lengkap untuk analisis deskriptif. Pada Gambar 1 menunjukkan proses seleksi dalam penelitian ini. 

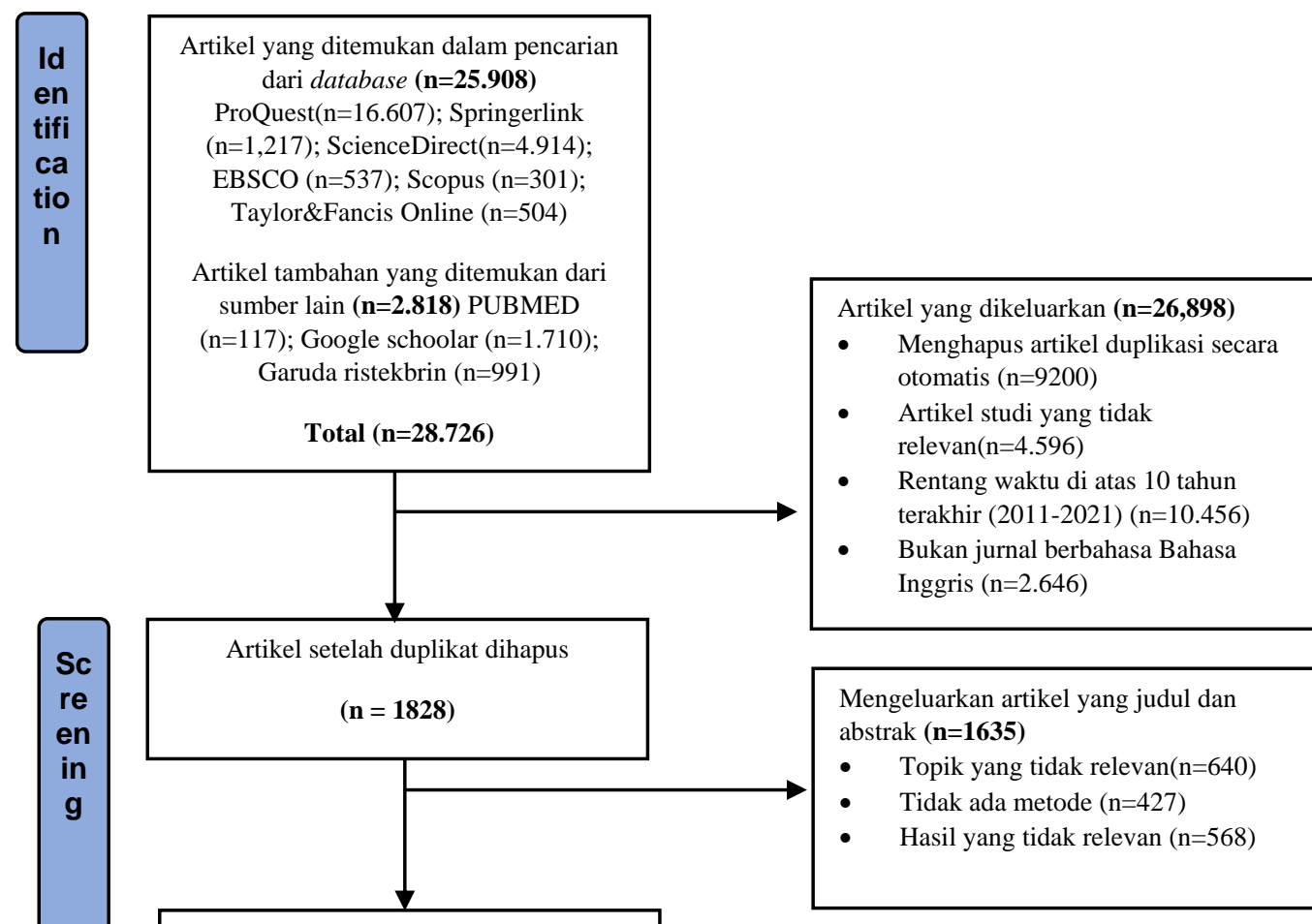

Mengeluarkan artikel yang judul dan abstrak (n=1635)

- Topik yang tidak relevan( $(\mathrm{n}=640)$

- Tidak ada metode $(n=427)$

- Hasil yang tidak relevan $(\mathrm{n}=568)$
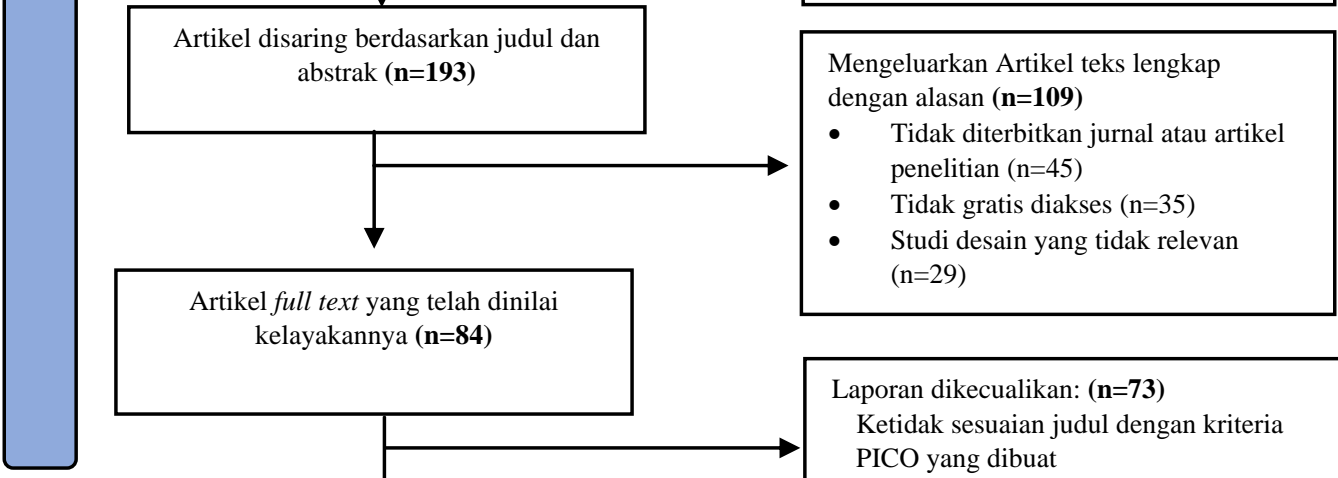

Artikel full text yang telah dini kelayakannya $(\mathbf{n}=\mathbf{8 4})$

Laporan dikecualikan: $(\mathbf{n}=\mathbf{7 3})$ Ketidak sesuaian judul dengan kriteria PICO yang dibuat
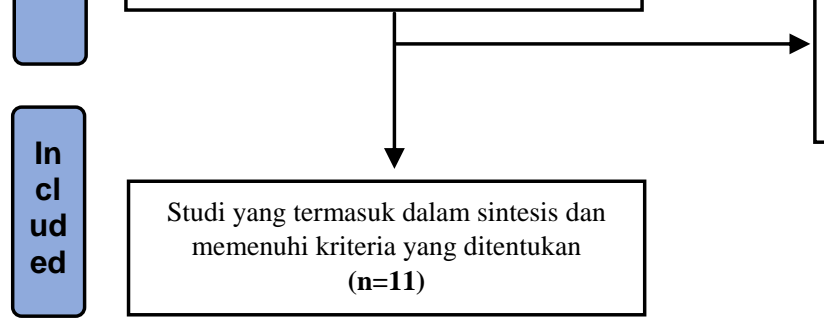

Studi yang termasuk dalam sintesis dan memenuhi kriteria yang ditentukan $(\mathbf{n}=11)$

Gambar 1. Bagan Alur Seleksi studi menurut pedoman PRISMA 2020 Sumber: The PRISMA 2020 statement: an updated guideline for reporting systematic reviews.

\section{HASIL}

Hasil identifikasi sebelas artikel terpilih yang memenuhi syarat untuk dianalisis, dari berbagai negara. Desain penelitian yang digunakan dari masing-masing studi tersebut sebagai berikut: case study participative, kualitatif, kuantitatif, wawancara mendalam, metode campuran. Penelitian ini ditemukan hasil penerapan BSC yang dapat dimodifikasi 
untuk mendapatkan indikator penilaian kinerja perusahaan termasuk rumah sakit dengan kombinasi Analisis SWOT, Key Performance Activity, Key Performance Indicator, analisis tujuan juga kombinasi keterkaitan visi dan misi perusahaan.

Tabel 1 adalah analisis perbandingan penelitian dari segi Metode, tujuan, manfaat dan temuan penulis. Beberapa penelitian menunjukkan bahwa adanya manfaat dari penerapan BSC di fasilitas kesehatan termasuk rumah sakit dapat membantu menerapkan praktik manajemen terkait pengukuran kinerja untuk meningkatkan mutu pelayanan untuk kebutuhan pasien sebagai pelanggan. Manfaat lain adalah penerapan BSC dapat memberikan solusi untuk masalah para manajer dari semua sektor pembangunan sosial yang terkait dengan hubungan antara strategi, aset tidak berwujud dan kinerja organisasi.

Tabel 2 menganalisis perbandingan hasil penelitian dan kesimpulan dari sebelas artikel yang dipilih, hampir semua hasil penelitian ini menunjukkan bahwa penggunaan BSC dianggap sebagai kerangka kerja pengukuran kinerja yang efektif yang beruna untuk mengevaluasi rencana strategis dari manajemen rumah sakit karena tidak hanya menilai dari aspek keuangan saja, tetapi juga dari tiga aspek lainnya seperti; perspektif pelanggan, perspektif bisnis internal dan perspektif pertumbuhan dan perkembangan. Beberapa penelitian juga menemukan bahwa penerapan strategi BSC dapat dimodifikasi dengan menggunakan analisis SWOT, nilai-nilai termasuk kualitas tinggi di bidang pengajaran, penelitian dan penetapan homepage pada profil website internet rumah sakit dan dapat dikaitkan dengan misi dan perencanaan strategis lain rumah sakit.

Tabel 1. Metode, Tujuan, Manfaat Dan Temuan Penulis

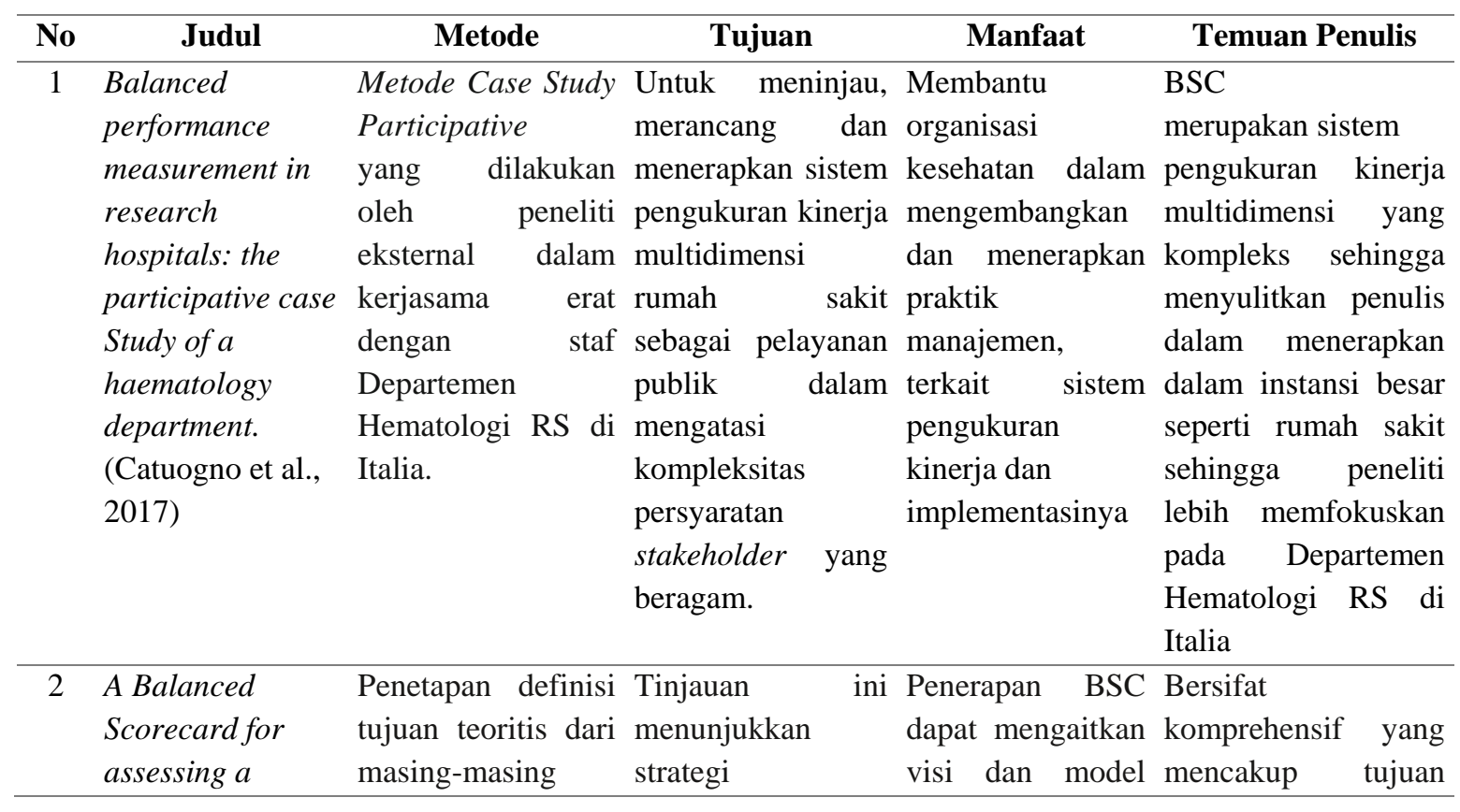




\begin{tabular}{|c|c|c|c|c|c|}
\hline & $\begin{array}{l}\text { strategic plan in } \\
\text { a clinical } \\
\text { laboratory. } \\
\text { (Alvarez et al., } \\
2019 \text { ) }\end{array}$ & $\begin{array}{lr}\text { perspektif } & \text { yang } \\
\text { paling banyak } \\
\text { digunakan dalam } \\
\text { pengelolaan } \\
\text { laboratorium klinis }\end{array}$ & $\begin{array}{l}\text { pengembangan } \\
\text { BSC, yang } \\
\text { mencakup tujuan } \\
\text { perspektif teoritis, } \\
\text { serta beberapa } \\
\text { indikator } \\
\text { pencapaian } \\
\text { rencana strategis di } \\
\text { Laboratorium } \\
\text { klinis }\end{array}$ & $\begin{array}{l}\text { organisasi } \\
\text { laboratorium } \\
\text { dalam pembuatan } \\
\text { peta strategis, } \\
\text { perspektif dan } \\
\text { tujuan organisasi }\end{array}$ & $\begin{array}{lr}\text { teoritis untuk setiap } \\
\text { perspektif dan tujuan } \\
\text { yang ingin dicapai, } \\
\text { sehingga } \\
\text { menjadi alat yang } \\
\text { valid, } \\
\text { dikelola mudah } \\
\text { sederhana } \\
\text { pencapaian } \\
\text { institusi }\end{array}$ \\
\hline 3 & $\begin{array}{l}\text { Adaptation of the } \\
\text { Balanced } \\
\text { Scorecard model } \\
\text { to measure } \\
\text { Performance of } \\
\text { the departments } \\
\text { at dr. Zainoel } \\
\text { Abidin regional } \\
\text { General hospital, } \\
\text { Banda Aceh. } \\
\text { (Martunis et al., } \\
\text { 2020) }\end{array}$ & $\begin{array}{l}\text { Penelitian ini } \\
\text { menggunakan } \\
\text { pendekatan } \\
\text { kualitatif } \\
\text { kuantitatif. dan } \\
\text { Teknik } \\
\text { pengumpulan data } \\
\text { yang digunakan } \\
\text { meliputi } \\
\text { wawancara, } \\
\text { observasi, dan } \\
\text { dokumentasi. }\end{array}$ & $\begin{array}{l}\text { Penelitian ini } \\
\text { bertujuan untuk } \\
\text { mengetahui kinerja } \\
\text { manajemen RSUD } \\
\text { dr. Zainoel } \\
\text { Banda Acidin } \\
\text { Indonesia tahun } \\
2016 \text { berdasarkan } \\
\text { target dan realisasi } \\
\text { program kerjanya } \\
\text { dengan } \\
\text { menggunakan } \\
\text { pendekatan BSC }\end{array}$ & $\begin{array}{l}\text { Mendorong } \\
\text { karyawan untuk } \\
\text { mencapai } \\
\text { Tujuan organisasi } \\
\text { dan memenuhi } \\
\text { standar perilaku } \\
\text { yang telah } \\
\text { ditentukan } \\
\text { sehingga } \\
\text { menghasilkan } \\
\text { Tindakan dan } \\
\text { hasil yang } \\
\text { diinginkan } \\
\text { organisasi. }\end{array}$ & $\begin{array}{l}\text { BSC bukan hanya } \\
\text { alat penilaian kinerja, } \\
\text { tetapi lebih lanjut } \\
\text { berkembang menjadi } \\
\text { sistem manajemen } \\
\text { strategis yang } \\
\text { membantu } \\
\text { menerjemahkan dan } \\
\text { mengkomunikasikan } \\
\text { visi dan misi dari } \\
\text { organisasi }\end{array}$ \\
\hline 4 & $\begin{array}{l}\text { Development of a } \\
\text { Balanced } \\
\text { Scorecard as a } \\
\text { strategic } \\
\text { performance } \\
\text { measurement } \\
\text { system for } \\
\text { clinical radiology } \\
\text { as a cost center. } \\
\text { (Teichgräber et } \\
\text { al., 2021) }\end{array}$ & $\begin{array}{l}\text { Pengembangan } \\
\text { BSC: dengan } \\
\text { mengkombinasikan } \\
\text { dengan Analisis } \\
\text { SWOT }\end{array}$ & $\begin{array}{l}\text { Mengembangkan } \\
\text { sistem indikator } \\
\text { yang berorientasi } \\
\text { pada tujuan } \\
\text { berdasarkan } \\
\text { konsep BSC dalam } \\
\text { mempertimbangka } \\
\text { n perspektif dokter } \\
\text { dalam } \\
\text { mendiagnosis dan } \\
\text { kebutuhan pasien } \\
\text { pada Departemen } \\
\text { Radiologi. }\end{array}$ & $\begin{array}{l}\text { BSC } \\
\text { memungkinkan } \\
\text { untuk } \\
\text { menerapkan } \\
\text { strategi radiologi } \\
\text { yang berorientasi } \\
\text { pada kebutuhan } \\
\text { dokter dalam } \\
\text { menegakan dan } \\
\text { diagnosis debutuhan pasien } \\
\text { kebutula }\end{array}$ & $\begin{array}{l}\text { Dalam penelitian ini } \\
\text { menerjemahkan } \\
\text { analisis SWOT ke } \\
\text { dalam } 4 \text { perspektif } \\
\text { dan definisi isu } \\
\text { strategis yang ada } \\
\text { dalam komponen } \\
\text { BSC untuk } \\
\text { menghasilkan } \\
\text { indikator penilaian } \\
\text { kinerja di unit } \\
\text { Radiologi }\end{array}$ \\
\hline 5 & $\begin{array}{l}\text { The mediating } \\
\text { effects of finance } \\
\text { on the } \\
\text { performance of } \\
\text { hospital facilities } \\
\text { management } \\
\text { services. (Amos } \\
\text { et al., 2021) }\end{array}$ & $\begin{array}{l}\text { Mix method, atau } \\
\text { metode campuran } \\
\text { paralel konvergen } \\
\text { dan sekuensial } \\
\text { eksploratif. }\end{array}$ & $\begin{array}{lr}\text { Menguji } & \text { efek } \\
\text { mediasi } & \text { keuangan } \\
\text { pada } & \text { kinerja } \\
\text { layanan } & \\
\text { manajemen } & \\
\text { fasilitas } & \text { rumah } \\
\text { sakit. } & \end{array}$ & $\begin{array}{l}\text { Memotivasi } \\
\text { manajemen } \\
\text { rumah sakit untuk } \\
\text { memprioritaskan } \\
\text { manajemen } \\
\text { fasilitas di rumah } \\
\text { sakit sebagai } \\
\text { bagian dari SDM } \\
\text { dalam } \\
\text { meningkatkan } \\
\text { pelayanan }\end{array}$ & $\begin{array}{l}\text { Mengadaptasi } \\
\text { perspektif BSC } \\
\text { dalam menganalisis } \\
\text { efek tidak langsung } \\
\text { keuangan pada } \\
\text { hubungan antara } \\
\text { kualitas layanan, } \\
\text { pembelajaran \& } \\
\text { pertumbuhan, bisnis } \\
\text { internal dan kinerja } \\
\text { manajemen fasilitas }\end{array}$ \\
\hline
\end{tabular}


Samuel Lay Riwu, Adik Wibowo, Kevin Chrisanta Budiyatno : Penilaian Kinerja Rumah Sakit Dengan ....

rumah sakit

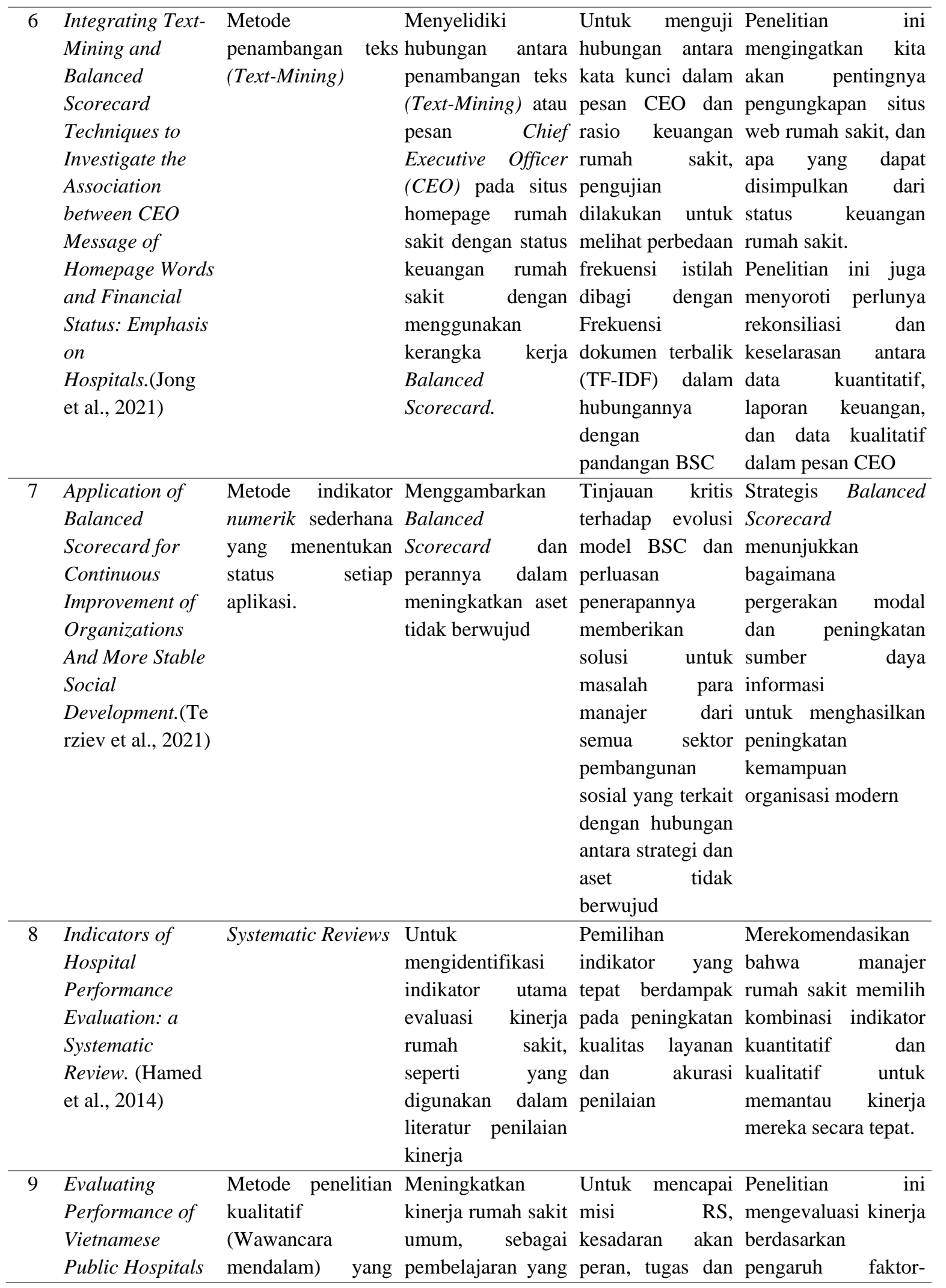




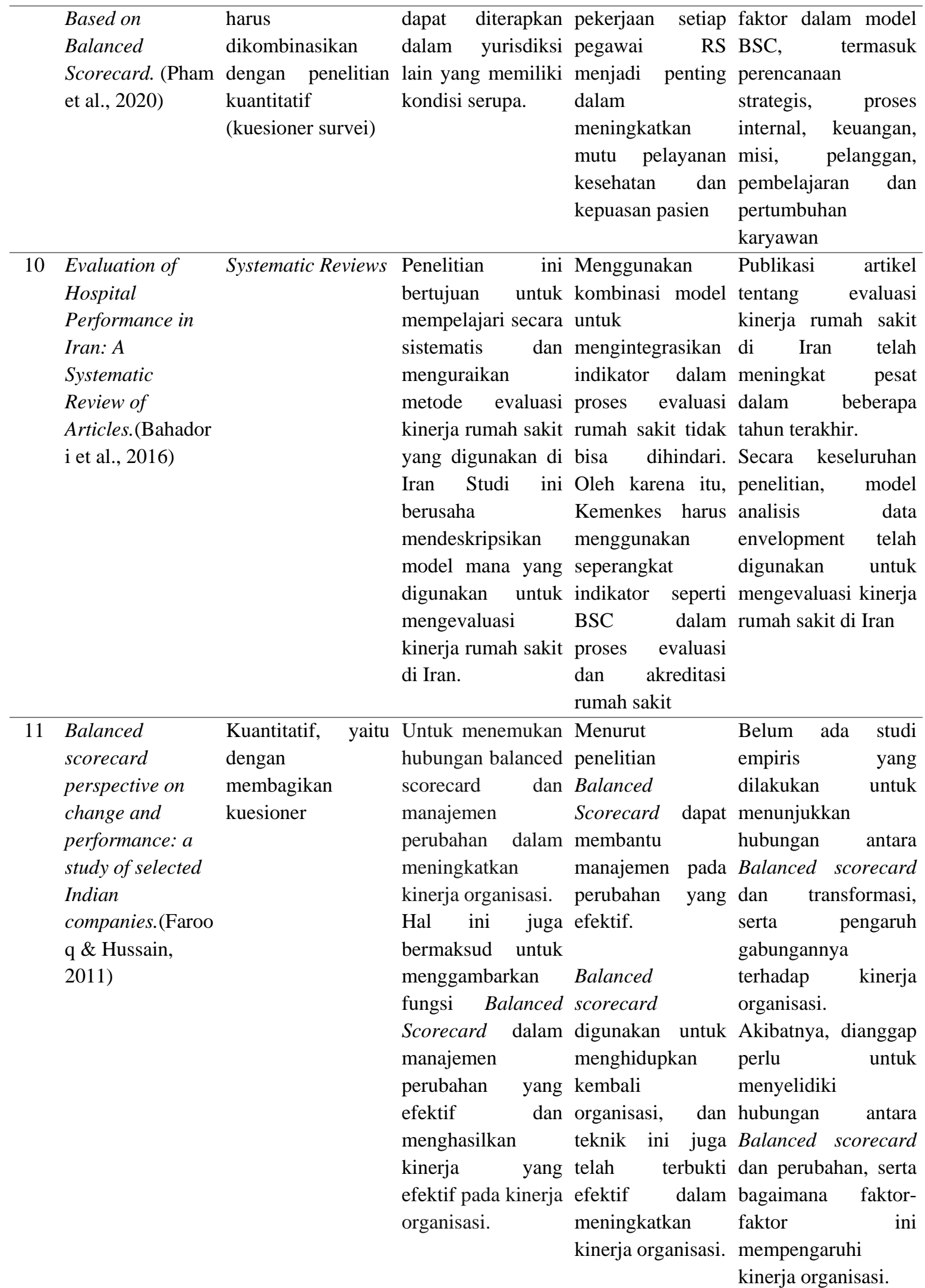


Samuel Lay Riwu, Adik Wibowo, Kevin Chrisanta Budiyatno : Penilaian Kinerja Rumah Sakit Dengan ....

Tabel 2. Hasil dan Kesimpulan

\begin{tabular}{|c|c|c|c|}
\hline No & Judul & Hasil & Kesimpulan \\
\hline 1 & $\begin{array}{l}\text { Balanced } \\
\text { performance } \\
\text { measurement in } \\
\text { research hospitals: } \\
\text { the participative case } \\
\text { Study of a } \\
\text { haematology } \\
\text { department. } \\
\text { (Catuogno et al., } \\
\text { 2017) }\end{array}$ & $\begin{array}{l}\text { Penelitian ini mengembangkan dan menerapkan } \\
\text { versi Balanced Scorecard yang sesuai dengan } \\
\text { serangkaian ukuran kinerja baru. } \\
\text { Penelitian ini menunjukkan bahwa BSC dapat } \\
\text { dianggap sebagai kerangka kerja yang efektif } \\
\text { untuk mengukur kinerja rumah sakit, dengan } \\
\text { kombinasi faktor yang dapat digeneralisasikan } \\
\text { dan konteks spesifik. }\end{array}$ & $\begin{array}{l}\text { Balanced scorecard dapat } \\
\text { disesuaikan untuk penelitian } \\
\text { rumah sakit dan menarik bagi } \\
\text { organisasi kesehatan yang } \\
\text { kompleks dalam menerapkan } \\
\text { praktik akuntansi manajemen }\end{array}$ \\
\hline 2 & $\begin{array}{l}\text { A Balanced } \\
\text { Scorecard for } \\
\text { assessing a strategic } \\
\text { plan in a clinical } \\
\text { laboratory. (Alvarez } \\
\text { et al., 2019) }\end{array}$ & $\begin{array}{l}\text { Hasilnya dimana Balanced Scorecard berguna } \\
\text { untuk mengevaluasi rencana strategis dalam } \\
\text { manajemen rumah sakit dan akan menyediakan } \\
\text { alat yang berguna untuk badan pengelolaan } \\
\text { laboratorium klinis baik untuk menggambarkan } \\
\text { visi dan strategi laboratorium. }\end{array}$ & $\begin{array}{l}\text { Penerapan Balanced } \\
\text { Scorecard lebih diaplikasikan } \\
\text { pada tujuan perancangan peta } \\
\text { strategis dari laboratorium } \\
\text { klinis. }\end{array}$ \\
\hline 3 & $\begin{array}{l}\text { Adaptation of the } \\
\text { Balanced Scorecard } \\
\text { model to measure } \\
\text { Performance of the } \\
\text { departments at dr. } \\
\text { Zainoel Abidin } \\
\text { regional General } \\
\text { hospital, Banda Aceh. } \\
\text { (Martunis et al., } \\
\text { 2020) }\end{array}$ & $\begin{array}{l}\text { Hasil keseluruhan penilaian } \\
\text { menggunakan pendekatan } \\
\text { dilihat dari empat perspektif yaitu: keuangan, } \\
\text { bisnis internal, pelanggan, pelatihan dan } \\
\text { pembelajaran sudah cukup baik. }\end{array}$ & $\begin{array}{l}\text { Penggunaan } \\
\text { Scorecard sebagai metode } \\
\text { untuk melakukan penilaian } \\
\text { kinerja memang lebih } \\
\text { banyak dijumpai pada } \\
\text { perusahaan bisnis yang } \\
\text { memproduksi barang, namun } \\
\text { dapat juga diterapkan pada } \\
\text { rumah sakit } \\
\text { menjalankan yang } \\
\text { penyediaan jasa. }\end{array}$ \\
\hline 4 & $\begin{array}{l}\text { Development of a } \\
\text { Balanced Scorecard } \\
\text { as a strategic } \\
\text { performance } \\
\text { measurement system } \\
\text { for clinical radiology } \\
\text { as a cost center. } \\
\text { (Teichgräber et al., } \\
\text { 2021) }\end{array}$ & $\begin{array}{l}\text { Sebanyak } 10 \text { faktor keberhasilan diidentifikasi } \\
\text { menggunakan analisis SWOT. Nilai-nilai inti } \\
\text { termasuk kualitas tinggi di bidang klinis, } \\
\text { pengajaran, dan penelitian. }\end{array}$ & $\begin{array}{l}\text { Pemantauan kinerja berbasis } \\
\text { BSC dapat membantu rumah } \\
\text { sakit mengatasi kelemahan } \\
\text { pada sistem pelaporan dan } \\
\text { untuk memenuhi persyaratan } \\
\text { berbeda dari sistem pelaporan } \\
\text { berorientasi tujuan, } \\
\text { manajemen strategis dan } \\
\text { operasional. }\end{array}$ \\
\hline 5 & $\begin{array}{l}\text { The mediating effects } \\
\text { of finance on the } \\
\text { performance of } \\
\text { hospital facilities } \\
\text { management services. } \\
\text { (Amos et al., 2021) }\end{array}$ & $\begin{array}{l}\text { Penelitian ini memperluas pengetahuan tentang } \\
\text { hubungan antara indikator penilaian kinerja } \\
\text { dengan kinerja manajemen fasilitas yang } \\
\text { berfokus pada tiga aspek mendasar dari BSC. } \\
\text { Penelitian ini juga menggambarkan model } \\
\text { struktural fasilitas manajemen } \\
\text { indikator penilaian kinerja mempengaruhi dan } \\
\text { memprediksi layanan manajemen fasilitas yang } \\
\text { berdampak pada hasil kinerja. }\end{array}$ & $\begin{array}{l}\text { Pendekatan } r \text { BSC } \\
\text { menunjukkan bahwa ketiga } \\
\text { efek tidak langsung } \\
\text { menunjukkan hubungan yang } \\
\text { signifikan; khususnya, } \\
\text { kualitas pelayanan. }\end{array}$ \\
\hline
\end{tabular}




\begin{tabular}{|c|c|c|c|}
\hline & $\begin{array}{l}\text { Integrating Text- } \\
\text { Mining and Balanced } \\
\text { Scorecard Techniques } \\
\text { to Investigate the } \\
\text { Association between } \\
\text { CEO Message of } \\
\text { Homepage Words } \\
\text { and Financial Status: } \\
\text { Emphasis on } \\
\text { Hospitals.(Jong et al., } \\
\text { 2021) }\end{array}$ & $\begin{array}{l}\text { Ditemukan ada beberapa hubungan yang } \\
\text { signifikan antara konten kualitatif dari homepage } \\
\text { rumah sakit dan rasio keuangan kuantitatif yang } \\
\text { menunjukkan profitabilitas, aktivitas, leverage, } \\
\text { likuiditas, dan akumulasi cadangan untuk tujuan } \\
\text { bisnis yang tepat. }\end{array}$ & $\begin{array}{l}\text { Bagian pengenalan dari } \\
\text { sebuah homepage merupakan } \\
\text { bagian yang paling mudah } \\
\text { diakses oleh pelanggan, } \\
\text { memuat tujuan dan cita-cita } \\
\text { rumah sakit serta } \\
\text { mencerminkan nilai dan visi } \\
\text { institusi. }\end{array}$ \\
\hline 7 & $\begin{array}{l}\text { Application of } \\
\text { Balanced Scorecard } \\
\text { for Continuous } \\
\text { Improvement of } \\
\text { Organizations And } \\
\text { More Stable Social } \\
\text { Development.(Terziev } \\
\text { et al., 2021) }\end{array}$ & $\begin{array}{l}\text { Evolusi Metode Balanced Scorecard dan } \\
\text { penerapannya memberikan solusi untuk masalah } \\
\text { dua dimensi utama bagi para manajer dari semua } \\
\text { sektor pembangunan sosial yang terkait dengan } \\
\text { hubungan antara strategi dan aset tidak berwujud. } \\
\text { Pada satu sisi, strategis Balanced Scorecard } \\
\text { menunjukkan bagaimana mobilisasi modal } \\
\text { manusia dan peningkatan sumber daya informasi } \\
\text { meningkatkan kemampuan organisasi modern } \\
\text { untuk menghasilkan nilai, dan di sisi lain } \\
\text { memikirkan kembali strategis Balanced } \\
\text { Scorecard berdasarkan pengembangan modal } \\
\text { organisasi. }\end{array}$ & $\begin{array}{l}\text { Faktor utama keberhasilan } \\
\text { adalah ketersediaan dan } \\
\text { keberadaan modal organisasi. } \\
\text { Dalam struktur aset organisasi } \\
\text { dan khususnya di antara yang } \\
\text { tidak berwujud, peran utama } \\
\text { dimiliki oleh aset yang } \\
\text { dirangkum dalam kategori } \\
\text { "Human capital". } \\
\text { Pengembangan } \\
\text { informasi berbasis sistem, } \\
\text { jaringan, database dan } \\
\text { perpustakaan menciptakan } \\
\text { peluang bagi setiap strategi } \\
\text { organisasi untuk menjadi } \\
\text { efisien } \\
\text { dan sangat efektif. }\end{array}$ \\
\hline \multirow[t]{2}{*}{8} & $\begin{array}{l}\text { Indicators of Hospital } \\
\text { Performance } \\
\text { Evaluation: A } \\
\text { Systematic Review. } \\
\text { (Hamed et al., 2014) }\end{array}$ & $\begin{array}{l}\text { Hasil penelitian ini memungkinkan stakeholder } \\
\text { yang berbeda untuk membuat penilaian yang } \\
\text { komprehensif terhadap rumah sakit mereka. } \\
\text { Penggunaan indikator tergantung pada model, } \\
\text { eksekutif, tujuan manajer, dan sudut pandang } \\
\text { penilai. }\end{array}$ & $\begin{array}{l}\begin{array}{l}\text { Evaluator sebagian besar } \\
\text { tertarik menggunakan }\end{array} \\
\text { indikator kuantitatif dalam } \\
\text { penilaian kinerja rumah sakit. } \\
\text { Selain itu, berbagai indikator } \\
\text { digunakan untuk } \\
\text { mengevaluasi kualitas layanan }\end{array}$ \\
\hline & & $\begin{array}{l}\text { Menunjukkan bahwa evaluator sebagian besar } \\
\text { tertarik pada indikator kuantitatif untuk penilaian } \\
\text { kinerja rumah sakit. }\end{array}$ & $\begin{array}{l}\text { rumah sakit. } \\
\text { Direkomendasikan bahwa } \\
\text { manajer rumah sakit memilih } \\
\text { kombinasi indikator } \\
\text { kuantitatif dan kualitatif untuk } \\
\text { pemantauan akurat kinerja } \\
\text { rumah sakit }\end{array}$ \\
\hline \multirow[t]{2}{*}{9} & $\begin{array}{l}\text { Evaluating } \\
\text { Performance of } \\
\text { Vietnamese Public }\end{array}$ & $\begin{array}{l}\text { Perlu mengelola setiap kegiatan RS, menetapkan } \\
\text { prioritas tugas untuk mencapai misi RS. }\end{array}$ & $\begin{array}{l}\text { Terdapat hubungan positif } \\
\text { antara kinerja rumah sakit } \\
\text { dengan: }\end{array}$ \\
\hline & $\begin{array}{l}\text { Hospitals Based on } \\
\text { Balanced Scorecard. } \\
\text { (Pham et al., 2020) }\end{array}$ & $\begin{array}{l}\text { Perlunya menetapkan tujuan jangka panjang RS } \\
\text { dan untuk mewujudkan tujuan tersebut perlu } \\
\text { disadari peran strategi terhadap misi RS dan }\end{array}$ & $\begin{array}{ll}\text { - } & \text { Faktor perencanaan } \\
& \text { strategis } \\
\text { - Faktor misi } & \end{array}$ \\
\hline
\end{tabular}


mengimplementasikan strategi operasional.

Untuk mencapai misi RS, perlu disadari pelaksanaan tugas setiap individu dan seluruh staf RS. Ini telah diterapkan di RS, tetapi tidak benar-benar menyeluruh dan efektif

- Faktor pelanggan

- Faktor proses internal

- Faktor pembelajaran dan pertumbuhan pegawai

- Faktor keuangan

Sementara faktor tersisa lainnya adalah perencanaan strategis, pelanggan, pembelajaran dan pertumbuhan karyawan, yang menunjukkan dampak positif terhadap kinerja rumah sakit umum di provinsi tersebut.

$10 \begin{aligned} & \text { Evaluation of } \\ & \text { Hospital } \\ & \text { Performance in Iran: } \\ & \text { A Systematic Review } \\ & \text { of Articles.(Bahadori } \\ & \text { et al., 2016) }\end{aligned}$

Publikasi artikel tentang evaluasi kinerja rumah sakit di Iran telah meningkat pesat dalam beberapa tahun terakhir.

Secara keseluruhan penelitian, model analisis data envelopment telah digunakan untuk mengevaluasi kinerja rumah sakit di Iran
Penggunaan kombinasi model untuk mengintegrasikan indikator dalam proses evaluasi rumah sakit tidak dapat dihindari. Oleh karena itu, Kementerian Kesehatan dan Pendidikan Kedokteran hendaknya menggunakan seperangkat indikator seperti Balanced Scorecard dalam proses evaluasi dan akreditasi rumah sakit serta mendorong pengelola rumah sakit untuk menggunakannya.

Daya tarik luas Balanced Scorecard sebagai strategi manajemen telah lama terbukti. BSC menciptakan kerangka kerja visual yang menghubungkan tujuan strategis organisasi dengan empat sudut pandang ini. Setiap inisiatif perubahan memiliki pengaruh jangka pendek dan jangka panjang pada keberhasilan organisasi.

\section{PEMBAHASAN}

Hasil penelitian menurut Catuogno pada tahun 2017 dengan menunjukkan bagaimana kerangka Balanced Scorecard dapat disesuaikan untuk penelitian rumah sakit, penelitian ini terutama menarik bagi organisasi kesehatan yang kompleks yang menerapkan praktik akuntansi manajemen. Penelitian ini berkontribusi pada literatur 
tentang penerapan Balanced Scorecard dalam perawatan kesehatan melalui pemeriksaan tantangan dalam merancang dan mengimplementasikan alat kinerja multidimensi ini. Ini adalah salah satu penelitian pertama yang menunjukkan bagaimana model Balanced Scorecard dapat disesuaikan agar sesuai dengan kebutuhan spesifik rumah sakit. (Catuogno et al., 2017)

BSC dikatakan komprehensif dan strategis karena mencakup tujuan teoritis pada setiap perspektif, serta indikator dan tujuan yang ingin dicapai, dapat menjadi alat yang valid, mudah dikelola, dan sederhana di laboratorium klinis untuk memantau dan mengukur secara kuantitatif tingkat pencapaian tujuan institusi.(Alvarez et al., 2019). Penelitian ini sejalan dengan apa yang dikemukakan oleh pakar sebelumnya yaitu Kaplan \& Norton tahun 1996 yang menyatakan bahwa Balanced Scorecard dapat menerjemahkan misi dan strategi organisasi ke dalam serangkaian langkah kinerja komprehensif yang menyediakan kerangka kerja untuk sistem pengukuran dan manajemen strategis (Kaplan \& Norton, 1996).

Keseluruhan hasil penilaian kinerja menggunakan pendekatan $B S C$ dilihat dari perspektif keuangan, bisnis internal, pelanggan, dan pelatihan dan pembelajaran baik. RSUD dr. Zainoel Abidin telah memberikan pelayanan yang baik dan kinerja departemennya telah menghasilkan outcome yang diharapkan dan diwujudkan oleh rumah sakit. Keterbatasan penelitian terletak pada variabel-variabel yang diteliti, yang berkaitan dengan manajemen strategis dan manajemen sumber daya manusia rumah sakit (terutama kepemimpinan transformasional, komitmen organisasi, implementasi keunikan dan kinerja sumber daya) dan pengelolaan keuangan rumah sakit (terutama pelaksanaan rencana bisnis, anggaran dan kinerja) (Martunis et al., 2020).

BSC memungkinkan untuk menerapkan strategi radiologi yang sangat berorientasi pada kebutuhan dokter yang merujuk dan tuntutan pasien. Secara keseluruhan, contoh departemen radiologi ini menunjukkan bahwa pemantauan berbasis BSC juga dapat membantu rumah sakit mengatasi kelemahan sistem pelaporan berorientasi anggaran tradisional dan untuk dapat menggunakan kartu skor yang berbeda untuk memenuhi persyaratan berbeda dari sistem pelaporan berorientasi tujuan. manajemen strategis dan operasional (Teichgräber et al., 2021).

Penerapan BSC dalam memfasilitasi kinerja layanan (Facility Management) FM, pembelajaran dan pertumbuhan dan bisnis internal memiliki hubungan yang signifikan secara statistik dengan kinerja FM. (Amos et al., 2021) Menariknya, hubungan antara ketiga konstruksi dan kinerja ini juga dimediasi oleh keuangan. Meskipun keuangan telah 
menjadi kendala untuk berfungsinya layanan kesehatan secara efisien dan layanan pendukungnya di rumah sakit umum, sedikit yang diketahui tentang efek mediasi pada kinerja FM dalam literatur. Hasil kami menunjukkan pengaruh keuangan dalam memfasilitasi kinerja layanan FM. Studi ini menegaskan semua tiga hipotesis. Secara spesifik, kualitas penyampaian layanan FM sangat penting untuk pemberian layanan kesehatan. Kualitas layanan telah dikaitkan secara positif dengan kinerja organisasi. Meskipun secara umum diakui bahwa pembiayaan tetap menjadi tantangan untuk pemberian layanan kesehatan di sebagian besar negara berkembang, perbedaan alokasi sumber daya di rumah sakit menyebabkan kerugian dari layanan dukungan non-klinis, yang komponen terbesarnya adalah bangunan dan layanan terkait. Tidak dapat disangkal, kekuatan finansial FM diperlukan untuk pemberian layanan yang lebih baik, yang selalu mempengaruhi perawatan kesehatan inti dan kinerja rumah sakit. Penelitian ini bertujuan untuk memediasi pengaruh tidak langsung keuangan terhadap kinerja FM menggunakan KPI yang dibuat dari kombinasi literatur dan wawancara ahli.

Penelitian yang dilakukan oleh Jong et all, tahun 2021 mengingatkan kita akan pentingnya penyampaian pada Chief Executive Officer (CEO) situs web rumah sakit dan apa yang dapat disimpulkan dari status keuangan rumah sakit. Ini juga menyoroti perlunya rekonsiliasi dan keselarasan antara data kuantitatif, laporan keuangan dengan data kualitatif dalam pesan yang disampaikan CEO pada situs homepage rumah sakit.(Jong et al., 2021) Bagian pengenalan dari sebuah homepage merupakan bagian yang paling mudah diakses oleh pelanggan, memuat tujuan dan cita-cita rumah sakit serta mencerminkan nilai dan visi institusi. Selain itu, dalam cakupan status keuangan, organisasi dapat menekankan kekuatan keuangan atau fokus pada bidang lain untuk mengalihkan perhatian dari setiap kelemahan yang ditunjukkan dalam informasi keuangan.

Hasil penelitian ini sejalan dengan apa yang dikemukakan oleh Kaplan dan Norton (1996) awalnya mengembangkan BSC untuk sektor nirlaba (swasta) dan sebagai sebuah instrumen bagi manajer untuk mengarahkan daya saing perusahaan mereka dengan menekankan tidak hanya dalam mencapai tujuan keuangan, tetapi juga pada penggerak kinerja dari tujuan tersebut tujuan keuangan. Untuk organisasi nirlaba, Kaplan menemukan bahwa BSC, ketika diadopsi oleh sektor nirlaba, memungkinkan semua sumber daya organisasi (Kaplan \& Norton, 1996). 


\section{SIMPULAN}

Penerapan metode BSC di berbagai negara dalam penelitian ini sudah sangat baik diterapkan dalam suatu perusahaan termasuk rumah sakit karena tidak hanya melihat dari segi keuangan saja tetapi juga dapat melihat kinerja perusahaan tersebut dari sisi yang lebih komprehensif diantaranya perspektif bisnis internal, perspektif pertumbuhan perkembangan perusahaan dan dari segi pelanggan. Keberhasilan menerapkan BSC di rumah sakit tergantung pada seberapa serius pihak manajemen rumah sakit menempatkan perhatian mereka dalam penilaian kinerja dan memastikan ketersediaan sumber daya yang memiliki keterampilan dalam merumuskan hipotesis strategis, analisis data, dan manajemen data akan diperlukan.

Keterbatasan utama dari penelitian ini adalah kelangkaan studi BSC dari situs Indonesia (hanya satu studi yang ditemukan di Indonesia). Keterbatasan lainnya adalah kurangnya paparan data berisi informasi kuantitatif data yang dihasilkan oleh peneliti dari kegiatan pengolahan atau analisis data yang telah dikumpulkan, namun, sebagian besar penelitian ini menunjukkan betapa pentingnya penerapan BSC dalam praktek pengukuran kinerja dalam organisasi dan ini cukup baik diterapkan pada rumah sakit di Indonesia. Peranan BSC bukan saja sebagai alat penilaian kinerja tetapi lebih lanjut dapat juga berkembang menjadi sistem manajemen strategis yang dapat membantu menerjemahkan dan mengkomunikasikan visi dan misi rumah sakit yang sangat baik untuk kelangsungan organisasi.(Martunis et al., 2020).

\section{DAFTAR PUSTAKA}

Alvarez, L., Soler, A., Guiñón, L., \& Mira, A. (2019). A balanced scorecard for assessing a strategic plan in a clinical laboratory. Biochemia Medica, 29(2), 284-291. https://doi.org/10.11613/BM.2019.020601

Amos, D., Au-Yong, C. P., \& Musa, Z. N. (2021). The mediating effects of finance on the performance of hospital facilities management services. Journal of Building Engineering, 34(October 2020), 101899. https://doi.org/10.1016/j.jobe.2020.101899

Astuti, D., Noormansyah, I., \& Zulfiati, L. (2020). Pengaruh kinerja keuangan dan kinerja pelayanan terhadap tingkat kemandirian keuangan pada rumah sakit vertikal di bawah Kementerian Kesehatan. Jurnal Ekonometrika, 2(2).

Bahadori, M., Izadi, A. R., Ghardashi, F., Ravangard, R., \& Hosseini, S. M. (2016). The evaluation of hospital performance in Iran: A systematic review article. Iranian Journal of Public Health, 45(7), 855-866.

Broccardo, L. (2015). The balance scorecard implementation in the italian health care system: some evidences from literature and a case study analysis. Journal of Health Management, 17(1), 25-41. https://doi.org/10.1177/0972063414560868

Catuogno, S., Arena, C., Saggese, S., \& Sarto, F. (2017). Balanced performance measurement in research hospitals: The participative case study of a haematology 
Samuel Lay Riwu, Adik Wibowo, Kevin Chrisanta Budiyatno : Penilaian Kinerja Rumah Sakit Dengan ....

department. BMC Health Services Research, 17(1). https://doi.org/10.1186/s12913$017-2479-6$

Farooq, A., \& Hussain, Z. (2011). Balanced scorecard perspective on change and performance: A study of selected Indian companies. Procedia - Social and Behavioral Sciences, 24, 754-768. https://doi.org/10.1016/j.sbspro.2011.09.043

Hamed, R., Mohammad, K., Zahra, K., \& Marzieh., E. (2014). Indicators of Hospital performance evaluation : a systematic review. International Journal of Hospital Research, 3(4), 199-208.

Jong, H., Lee, K. C., \& Kim, S. T. (2021). Integrating text-mining and balanced scorecard techniques to investigate the association between ceo message of homepage words and financial status: Emphasis on hospitals. Healthcare (Switzerland), 9(4). https://doi.org/10.3390/healthcare9040408

Kaplan, R. S., \& Norton, D. P. (1996). The balanced scorecard (Translating strategy into action) (First eBoo). President and Fellows of Harvard College.

Korneles, V. W., Nangoi, G. B., \& Kalangi, L. (2019). Penilaian kinerja Rumah Sakit Umum Daerah setelah pelaksanaan pola pengelolaan keuangan BLUD pada Rumah Sakit Umum Daerah Liun Kendage Tahuna. Jurnal Riset Akuntansi Dan Auditing “Goodwill," 10(2), 184. https://doi.org/10.35800/jjs.v10i2.26379

Martunis, A., Dalimunthe, R., Amalia, K., Juanita, J., Syahputra, H., Adam, M., \& Masyudi, M. (2020). Adaptation of the balanced scorecard model to measure performance of the departments at dr Zainoel abidin regional general hospital, banda aceh. Journal of Modelling in Management, 15(2), 365-379. https://doi.org/10.1108/JM2-09-2018-0149

Page, M. J., McKenzie, J. E., Bossuyt, P. M., Boutron, I., Hoffmann, T. C., Mulrow, C. D., Shamseer, L., Tetzlaff, J. M., Akl, E. A., Brennan, S. E., Chou, R., Glanville, J., Grimshaw, J. M., Hróbjartsson, A., Lalu, M. M., Li, T., Loder, E. W., MayoWilson, E., McDonald, S., ... Moher, D. (2021, March 29). The PRISMA 2020 statement: An updated guideline for reporting systematic reviews. The BMJ; BMJ Publishing Group. https://doi.org/10.1136/BMJ.N71

Pham, C. D., Vu, S. T., Pham, Y. T. K., \& Vu, N. T. (2020). Evaluating performance of Vietnamese public hospitals based on balanced scorecard. Journal of Asian Finance, $\begin{array}{llll}\text { Economics } \quad \text { and 339-349. } & \text { 3(6), }\end{array}$ https://doi.org/10.13106/JAFEB.2020.VOL7.NO6.339

Teichgräber, U., Sibbel, R., Heinrich, A., \& Güttler, F. (2021). Development of a balanced scorecard as a strategic performance measurement system for clinical radiology as a cost center. Insights into Imaging, 12(1), 69. https://doi.org/10.1186/s13244-021-01009-2

Terziev, V., Georgiev, M., \& Ivanov, I. (2021). Application of balanced scorecard for continuous improvement of organizations and more stable social development. SSRN Electronic Journal, 177-185. https://doi.org/10.2139/ssrn.3772171

Yulianti, E., \& Diyani, L. A. (2017). Balanced Scorecard Sebagai Pengukuran. Wahana, 20(1), 57-73.

\begin{tabular}{|l|l|}
\hline Submission & $28-06-2021$ \\
\hline Review & $07-08-2021$ \\
\hline Accepted & $24-09-2021$ \\
\hline Publish & $29-10-2021$ \\
\hline DOI & 10.29241 jmk.v7i2.638 \\
\hline Sinta Level & 3 (Tiga) \\
\hline
\end{tabular}

